\title{
FIRST REPORT OF METALLO- $\beta$-LACTAMASES PRODUCING Enterobacter spp. STRAINS FROM VENEZUELA
}

Dianny MARTíNEZ(1,2), Hectorina E. RODULFO(1), Lucy RODRÍGUEZ(2), Luisa E. CAÑA(2), Belkis MEDINA(2), Militza GUZMAN(3), Numirin CARREÑO(1), Daniel MARCANO(4) \& Marcos DE DONATO(1)

\begin{abstract}
SUMMARY
Clinical strains of Enterobacter were isolated from Cumana's Central Hospital in Venezuela, and classified as E. cloacae (21), E. aerogenes (7), E. intermedium (1), E. sakazakii (1) and three unclassified. The strains showed high levels of resistance, especially to SXT (58.1\%), CRO (48.8\%), CAZ (46.6\%), PIP (46.4\%), CIP (45.2\%) and ATM (43.3\%). This is the first report for South America of bla $_{\mathrm{vIM}-2}$ in two E. cloacae and one Enterobacter sp., which also showed multiple mechanisms of resistance. Both E. cloacae showed $b l a_{\mathrm{TEM}-1}$, but only one showed $b l a_{\text {СTX-M-15 }}$ gene, while no $b l a_{\mathrm{SHV}}$ was detected.
\end{abstract}

KEYWORDS: Carbapenemase; Metallobetalactamase; VIM; Enterobacter; Carbapenems.

\section{INTRODUCTION}

Species of the genus Enterobacter have been reported as an important source of intrahospital infections, especially those showing resistance to betalactams by the production of enzymes like extended spectrum betalactamases (ESBL) such as TEM, SHV, CTX, VEB, and carbapenemases such as VIM, KPC and GES ${ }^{14}$. This represents an important therapeutic challenge because of the few remaining treatment options, which gives rise to morbimortality and hospital expenses.

There are reports of Enterobacter strains producing metallo- $\beta$ lactamase (MBL) in different parts of the world, such as E. cloacae in Japan, Taiwan, Korea and Italy, as well as E. aerogenes in Japan and France $^{2}$. However, no MBL-producing strains of Enterobacter have been reported anywhere in the Americas, except in Mexico $^{11}$ and Argentina ${ }^{4}$.

\section{METHODS}

During August 2010 and March 2011, clinical strains of Enterobacter were isolated in the University Hospital Antonio Patricio de Alcala in Cumana, Venezuela. The use of the strains was approved by the patients or their relatives, according to the recommendations of the Bioethics and Biosecurity Committee of IIBCA, Universidad de Oriente, Cumana, Venezuela.

Isolated strains were inoculated in BHI broth, incubated for 12 hours at $37{ }^{\circ} \mathrm{C}$ and later in MacConkey agar for 24 hours, in order to evaluate the morphological characteristics of the colonies to verify purity. For the classification of Enterobacter species tests for the fermentation of glucose and lactose in Kligler medium, use of citrate, arginine and malonate, use of MIO, LIA, and methyl red and Voges-Proskauer medium according to standard biochemical tests established for Enterobacteriaceae $e^{8,16}$.

Antimicrobial susceptibility was assessed by Kirby-Bauer disk diffusion susceptibility test following the recommendations of the Clinical and Laboratory Standards Institute (CLSI). For tigecycline (TGC), we used the cutoff of the attached insert (Pfizer, INC).

Screening of extended spectrum beta-lactamases (ESBL), were carried out using the synergy effect between the antimicrobial disks CAZ, FEP, CRO, ATM and CTX surrounding AMC as well as the confirmatory test for ESBL was carried out using the combined disc test ${ }^{7}$. Additionally, in order to detect the presence of ESBL enzymes we used the modification suggested by SONG et al. (2007), in order to avoid the masking effect that a derepressed AmpC gene could produce ${ }^{15}$. For this, disks containing CAZ $(30 \mu \mathrm{g})$ with and without clavulanic acid $(10 \mu \mathrm{g})$ were added 3-aminophenyl boronic acid with a final amount of $400 \mu \mathrm{g}$.

The phenotypic detection of MBLs was carried out using IPM and MER disks on each side of a disk with ethylendiaminotetracetic acid-sodium mercaptoacetate (EDTA-SMA, $0.5 \mu$ moles-3 $\mu \mathrm{g}$ ) and the combined disc test (IMP, IMP-EDTA and MER, MER-EDTA).

DNA extraction was carried out using the Wizard Genomic DNA kit (Promega) from the strains isolated after incubation in LB broth for 20 hours at $37^{\circ} \mathrm{C}$. The $b l a_{\mathrm{VIM}}$ gene was detected by PCR according

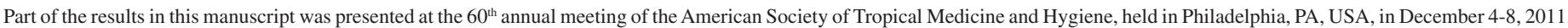
(1) Lab. Genetica Molecular, IIBCAUDO, Universidad de Oriente, Cumana, Venezuela.

(2) Lab. Bacteriologia, Hospital Universitario Antonio Patricio de Alcalá, Cumaná, Venezuela.

(3) Lab. de Bacteriologia Molecular, Dpto. Bioanalisis, Universidad de Oriente, Cumaná, Venezuela.

(4) Instituto Nacional de Higiene Dr Rafael Rangel, Caracas, Venezuela.

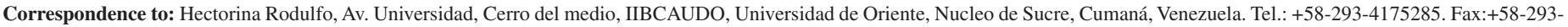
4521297. E-mail: hrodulfo2002@yahoo.es 
MARTÍNEZ, D.; RODULFO, H.E.; RODRÍGUEZ, L.; CAÑA, L.E.; MEDINA, B.; GUZMAN, M.; CARREÑO, N.; MARCANO, D. \& DE DONATO, M. - First report of metallo- $\beta$-lactamases producing Enterobacter spp. strains from Venezuela. Rev. Inst. Med. Trop. Sao Paulo, 56(1): 67-9, 2014.

to MENDEZ et al..$^{10}$. Additionally, we detected the type 1 and 2 bla $a_{\mathrm{VIM}}$ according to FIETT et $a l .{ }^{3}$. The genes bla ${ }_{\text {СTХ-м }}$ (EDELSTEIN et al. unpublished results, http://www.antibiotic.ru/en/pdfs/006-51.pdf), $b l a_{\mathrm{TEM}}$ and $b l a_{\mathrm{SHV}}{ }^{12}$ were also detected. Finally, in order to determine the clonality of the three Enterobacter strains showing a phenotype consistent with MBL by the IMP/MER/EDTA synergy test, we used ERIC-PCR ${ }^{13}$.

\section{RESULTS}

The 33 strains of Enterobacter isolated were classified as E. cloacae (21), E. aerogenes (7), E. intermedium (1), E. sakazakii (1) and three were not possible to classify.

Ten of the strains were from infections acquired outside the hospital and most of the intrahospitalary strains were isolated in ICU (5), internal medicine areas A and B (4), soft surgery hall (4), pediatric area (3) and neonatology (3).

Antimicrobial susceptibility tests show high levels of resistance in most of the strains, with resistance to SXT (58.1\%), CRO (48.8\%), CAZ (46.6\%), PIP (46.4\%), CIP (45.2\%) and ATM (43.3\%) being the highest (Fig. 1). However, all the strains were sensitive to TGC. Results of the synergy test between CAZ/FEP/CRO/CTX/ATM with AMC in 16 of the strains were compatible with ESBL enzymes. We found that these strains showed the typical phenotypic effect for ESBL enzymes when using the combined disc test as a confirmatory. Additionally, three of the Enterobacter strains (two E. cloacae and one Enterobacter sp.) were resistant to cabapenems showing also synergy between IPM/MER and EDTA, typical of MBL enzymes (Table 1). ERIC-PCR patterns show no similarities among these strains. They showed resistance to multiple families of antibiotics (MDRs) and two of them also showed presence of ESBL by the synergy assay. These strains amplified for bla $a_{\mathrm{VIM}-2}$ fragments $(801 \mathrm{bp})$. Furthermore, both strains of E. cloacae amplified the typical fragment of the $b l a_{\text {TEM }}$ gene (1080 bp), but only one of them amplified the fragment of the bla ${ }_{\text {Стх-м }}$ gene (543 bp), while no $b l a_{\text {SHV }}$ gene was detected.

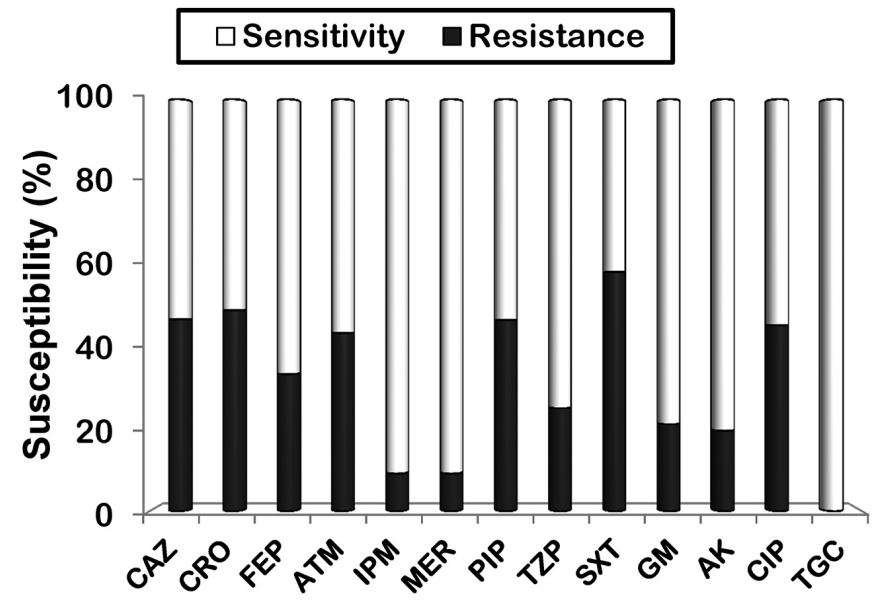

Fig. 1 - Antimicrobial susceptibility of the Enterobacter strains isolated in the Cumana hospital of Venezuela. CAZ: ceftazidime, CRO: ceftriaxone, FEP: cefepime, ATM: aztreonam, IPM: imipenem, MER: meropenem, PIP: piperacillin, TZP: piperacillin/tazobactam, SXT: trimethoprim-sulfamethoxazole, GM: gentamicin, AK: amikacin, CIP: ciprofloxacin and TGC: tigecycline.

Sequencing of the fragment of the $b l a_{\mathrm{VIM}}$ gene, amplified using primers for type 2, produced sequences $100 \%$ homologous to $b l a_{\mathrm{VIM}-2}$ reported in the GenBank in $P$. aeruginosa and other bacteria. Also, the sequences of the $b l a_{\text {TEM }}$ gene were $100 \%$ homologous to type 1 reported for many Enterobacteria. In addition, the fragment of the $b l a_{\text {СТХ-M }}$ gene sequenced showed $100 \%$ homology with CTX-M-15 found in E. coli and other Enterobacteria.

\section{DISCUSSION}

According to our phenotypic tests, BLEA and ESBL-type of enzymes was very prevalent. On the other hand, we are not aware of previous reports of the presence of VIM-producing Enterobacter strain in any South American country. In Mexico, strains of E. cloacae

Table 1

Resistance pattern and epidemiological data of the three strains of Enterobacter showing bla $_{\mathrm{VIM}}$ type 2 MBLs

\begin{tabular}{|c|c|c|c|c|c|c|}
\hline Species & Isolation date & Hospital area & Type of sample & Resistance pattern & Synergy tests & Detected genes \\
\hline E. cloacae & August 2010 & Soft Surgery & catheter & $\begin{array}{c}\text { CAZ, FEP, IPM, } \\
\text { MER, TZP, PIP, } \\
\text { CRO, ATM, SXT, } \\
\text { AK, GM }\end{array}$ & $\begin{array}{l}\text { ESBL, } \\
\text { MBL }\end{array}$ & $\begin{array}{l}b l a_{\mathrm{VIM}-2} \\
b l a_{\mathrm{TEM}-1} \\
b a_{\mathrm{CTX}-\mathrm{M}-15}\end{array}$ \\
\hline Enterobacter sp. & March 2011 & ICU & $\begin{array}{l}\text { bronchial } \\
\text { secretion }\end{array}$ & $\begin{array}{c}\text { CAZ, FEP, IPM, } \\
\text { MER, TZP, PIP, } \\
\text { CRO, ATM, SXT, } \\
\text { CIP }\end{array}$ & $\begin{array}{l}\text { AmpC, } \\
\text { MBL }\end{array}$ & $b l a_{\mathrm{VIM}-2}$ \\
\hline E. cloacae & April 2011 & $\begin{array}{c}\text { Internal } \\
\text { Medicine B }\end{array}$ & urine & $\begin{array}{l}\text { CAZ, FEP, IPM, } \\
\text { MER, TZP, PIP, } \\
\text { CTX, ATM, SXT, } \\
\text { CIP, AK }\end{array}$ & $\begin{array}{l}\text { ESBL, } \\
\text { MBL }\end{array}$ & $\begin{array}{l}b^{b l a}{ }_{\mathrm{VIM}-2} \\
b^{2} a_{\mathrm{TEM}-1}\end{array}$ \\
\hline
\end{tabular}

ESBL: extended-spectrum betalactamase, MBL: metallo- $\beta$-lactamase, AmpC: de-repression of the chromosomal AmpC gene. ICU: intensive care unit. Acronyms of antibiotic as shown in the legend of Fig. 1. 
MARTÍNEZ, D.; RODULFO, H.E.; RODRÍGUEZ, L.; CAÑA, L.E.; MEDINA, B.; GUZMAN, M.; CARREÑO, N.; MARCANO, D. \& DE DONATO, M. - First report of metallo-B-lactamases producing Enterobacter spp. strains from Venezuela. Rev. Inst. Med. Trop. Sao Paulo, 56(1): 67-9, 2014.

have been shown to produce $\mathrm{MBL}^{11}$. These strains produced bla $_{\mathrm{VIM}-2}$ MBLs, the same type we found in this study. In Argentina, one strain of E. cloacae was reported containing $b l a_{\mathrm{IMP}}$ gene, along with $b l a_{\mathrm{PER}}$ and genes that confer resistance to aminoglycosides and quinolones ${ }^{4}$. This type of gene has been reported in Venezuela but only in strains of Pseudomonas aeruginosa and Klebsiella pneumoniae ${ }^{5,9}$. VIMproducing $P$. aeruginosa strains were previously found in Cumana hospital (ENSONY TOVAR \& MARCOS DE DONATO, unpublished results). It seems very likely that the gene found in $P$. aeruginosa could have been transferred through mobile elements such as plasmid and/ or integrons between these two species which are sharing the same environment, as previously reported ${ }^{14}$, making possible the spread of this gene to many other bacteria species causing infection in this hospital environment.

The presence of multiple mechanisms of resistance in the bacteria isolated in the Cumana hospital causing intrahospital infections, especially in species of Enterobacter, which have natural resistance to several antibacterial drugs, suggests that more efficient preventive measures must be put in place in this hospital to avoid the survival and transmission of these strains. However, all the strains were susceptible to tigecycline, making it a suitable treatment for infections caused by MBL-producing enzymes in this hospital. This result agrees with numerous reports describing the use of tigecycline to treat infections caused by multidrug resistant bacteria, including those producing carbapenemases $^{14}$.

\section{AUTHOR CONTRIBUTIONS}

DM, LR and LC isolated the strains. HER, DM and MDD carried out the molecular analysis, BM, MG and $\mathrm{NC}$ helped in the bacteriological analysis. DM, HER and MDD wrote the manuscript and everyone reviewed the manuscript.

\section{RESUMEN}

\section{Primer reporte de cepas de Enterobacter spp productoras de metalobetalactamasas de Venezuela}

Cepas clínicas de Enterobacter fueron aisladas del Hospital central de Cumaná en Venezuela, y se clasificaron como E. cloacae (21), E. aerogenes (7), E. intermedium (1), E. sakazakii (1) y 3 sin clasificar. Las cepas mostraron altos niveles de resistencia, especialmente a SXT (58.1\%), CRO (48.8\%), CAZ (46.6\%), PIP (46.4\%), CIP (45.2\%) and ATM (43.3\%). Este es el primer reporte de América del Sur de bla $a_{\mathrm{VIM}-2}$ en dos cepas de E. cloacae y una de Enterobacter sp., las cuales también mostraron múltiples mecanismos de resistencia. Ambas especies de $E$. cloacae mostraron genes $b l a_{\mathrm{TEM}-1}$, pero solo una mostro el gen $b l a_{\mathrm{CTX}-\mathrm{M}-15}$, mientras que $b l a_{\mathrm{SHV}}$ no fue detectado.

\section{REFERENCES}

1. Betriu C, Rodríguez-Avial I, Gómez M, Culebras E, López F, Alvarez J, et al. Antimicrobial activity of tygecicline against clinical isolates from Spanish medical centers. Second multicenter study. Diagn Microbiol Infect Dis. 2006;56:437-44.
2. Falcone M, Mezzatesta ML, Perilli M, Forcella C, Giordano A, Cafiso V, et al. Infections with VIM-1 metallo-beta-lactamase-producing Enterobacter cloacae and their correlation with clinical outcome. J Clin Microbiol. 2009;47:3514-9.

3. Fiett J, Baraniak A, Mrówka A, Fleischer M, Drulis-Kawa Z, Naumiuk Ł, et al. Molecular epidemiology of acquired-metallo-beta-lactamase-producing bacteria in Poland. Antimicrob Agents Chemother. 2006;50:880-6.

4. Gomez S, Rapoport M, Togneri A, Viegas-Caetano J, Faccone D, Corso A, et al. Emergence of metallo- $\beta$-lactamases in Enterobacteriaceae from Argentina. Diagn Microbiol Infect Dis. 2011;69:94-7.

5. Guevara A, de Waard J, Araque M. Detección del gen blaVIM-2 en cepas de Pseudomonas aeruginosa productoras de metalo $\beta$-lactamasa aisladas en una unidad de cuidados intensivos en Ciudad Bolívar, Venezuela. Rev Chil Infect. 2009;26:336-41.

6. Lee K, Lim Y, Yong D, Yum J, Chong Y. Evaluation of the Hodge test and the imipenemEDTA double-disk synergy test for differentiating metallo-ß-lactamase-producing isolates of Pseudomonas spp. and Acinetobacter spp. J Clin Microbiol. 2003;41:46239 .

7. Lezameta L, Gonzáles-Escalante E, Tamariz JH. Comparación de cuatro metodos fenotipicos para la detección de beta-lactamasas de espectro extendido. Rev Peru Med Exp Salud Publica. 2010;27:345-51.

8. MacFaddin JE. Biochemical tests for identification of medical bacteria. $3^{\text {rd }}$ ed Bloomington: Lippincott Williams \& Wilkins; 2000.

9. Marcano D, Pasterán F, Rapoport M, Faccone D, Ugarte C, Salgado N, et al. First isolation of a VIM-producing Klebsiella pneumoniae from a seven-year-old child in Venezuela. J Infect Dev Ctries. 2008;2:241-4.

10. Mendes RE, Kiyota KA, Monteiro J, Castanheira M, Andrade SS, Gales AC, et al. Rapid detection and identification of metallo-beta-lactamase-encoding genes by multiplex real-time PCR assay and melt curve analysis. J Clin Microbiol. 2007;45:544-7.

11. Morfin-Otero R, Rodriguez-Noriega E, Deshpande LM, Sader HS, Castanheira M. Dissemination of a bla(VIM-2)-carrying integron among Enterobacteriaceae species in Mexico: report from the SENTRY Antimicrobial Surveillance Program. Microb Drug Resist. 2009; 15:33-5

12. Quinteros M, Radice M, Gardella N, Rodriguez MM, Costa N, Korbenfeld D, et al. Extended-spectrum $\beta$-lactamases in Enterobacteriaceae in Buenos Aires, Argentina, public hospitals. Antimicrob Agents Chemother. 2003;47:2864-7.

13. Reboli AC, Houston ED, Monteforte JS, Wood CA, Hamill RJ. Discrimination of epidemic and sporadic isolates of Acinetobacter baumannii by repetitive element PCR-mediated DNA fingerprinting. J Clin Microbiol. 1994;32:2635-40.

14. Sader HS, Castanheira M, Mendes RE, Toleman M, Walsh TR, Jones RN. Dissemination and diversity of metallo- $\beta$-lactamases in Latin America: report from the SENTRY Antimicrobial Surveillance Program. Int J Antimicrob Agents. 2005;25:57-61.

15. Song W, Bae I, Lee YN, Lee CH, Lee SH, Jeong SH. Detection of extended-spectrum $\beta$-lactamases by using boronic acid as AmpC $\beta$-lactamase inhibitor in clinical isolates of Klebsiella spp. and Escherichia coli. J Clin Microbiol. 2007;45:1180-4.

16. Winn WC, Allen S, Janda W, Koneman E, Procop G, Schreckenberger P, et al. Koneman's color atlas and textbook of diagnostic microbiology. $6^{\text {th }}$ ed. Bloomington: Lippincott Williams \& Wilkins; 2005.

Received: 13 December 2012

Accepted: 29 May 2013 